\title{
D-11 HIGH-RESOLUTION CHEMOSTRATIGRAPHY, BIOSTRATIGRAPHY AND PALEOCEANO- GRAPHIC SIGNIFICANCE OF THE THETYAN "LIVELLO SELLI" FROM THE HYBLA FORMATION, NW SICILY
}

A. BELLANCA' E. ERBA ${ }^{2}$, R. NERI' ', I. PREMOLI SILVA², M. SPROVIERI' F. TREMOLADA², D. VERGA², F. MELI ${ }^{1}$ and G. PETROLO'

- Palermo University, Dipartimento di Chimica e Fisica della Terra ed Applicazioni alle Georisorse e ai Rischi Naturali, Via Archirafi 36, 90123 Palermo, Italy

High-resolution curves of carbon and oxygen isotopes and of major and trace elements have been generated for the early Aptian "Livello Selli" (LS, OAE 1a) from the pelagic sedimentary sequence outcropping at Calabianca in the northwestern margin of Sicily. Detailed nannofossil and planktonic foraminiferal assemblage analyses provide biostratigraphy for correlation of the 13C curve with previous records (Jenkyns, 1995; Menegatti et al., 1998; Moullade et al., 1998; Erba et al., 1999; Bralower et al., 1999).

Quantitative investigations of nannofloras allowed the identification of several new events in the Upper Hauterivian to Lower Aptian interval, in addition to previously proposed FOs and LOs. In particular, in the Barremian/Aptian boundary interval the nannoconid group shows major changes and the following events were detected: (a) a nannoconid (essentially narrow-canal forms) decline in the uppermost Barremian; (b) the FO of N. truittii and wide-canal nannoconids outnumber the narrow-canal ones in the lowermost Aptian; (c) the nannoconid crisis (both narrow- and wide-canal forms) prior to the deposition of the LS black shales; (d) the nannoconid return after the FO of E. floralis above the Livello Selli.

In term of planktonic foraminifera the studied interval belongs to the Globigerinelloides blowi Zone (below) and the Leupoldina cabri Zone (above), the latter beginning close to the base of LS, whereas the uppermost metre is attributable to the top part of the Ticinella primula Zone of late Middle Albian age. Biostratigraphy suggests a hiatus in the Upper Barremian, between the LO of C. oblongata and the FO of R. irregularis and a major hiatus between the Late Aptian and the late Middle Albian.

Planktonic foraminifera are unevenly distributed throughout in term of both abundance and composition fluctuating from layer to layer. In the Barremian interval the assemblages are small and consist of few specimens and few species, followed at the base of the Lower Aptian by a gradual, even fluctuating, increase in abundance, diversity and overall size of the fauna. Higher in the Lower Aptian, still below the LS, planktonic foraminiferal assemblages are richer, mainly composed by round-chambered hedbergellids except for two layers where favusellids predominate. Within the Livello Selli, diversity and abundance of planktonic foraminifera range from few to absent; when present the assemblages are predominantly composed of pear-shaped (clavate) forms and rare leupoldinids. Above the LS, planktonic foraminifera become abundant, well diversified and of larger size with the assemblages composed of clavate morphotypes that alternate with leupoldinids and round-chambered hedbergellids especially toward the top. The LS corresponds to the "nannoconid crisis" and displays a major increase in abundance of R. terebrodentarius and A. infracretacea, both represented by normal- and large-sized specimens. Calcareous plankton assemblages suggest that the LS is a high productivity event, in agreement with previous interpretation of OAEl a from various oceans. 
The carbon isotope curve displays a monotonous trend below the LS interval, with most values between 1 and 2 _ä. An analogous trend is noted for the Middle Albian interval. The Livello Selli and the immediately overlying strata are marked by a peculiar profile with a first negative shift at the base of LS (from 1.8/2.0 to about 0 a) followed by a progressive increase of carbon isotopic ratios up to values of about 2.5 _ä which persist through the upper part of the Livello Selli. Another step-like positive shift marks the top of the LS interval, reaching _ 13C values of 3-3.5ä. These values, that are the maxima of the Aptian excursion, characterize most of the Upper Aptian.

Carbon isotope and trace element variations suggest a complex paleoceanographic evolution of the Thetyan basin during the LS deposition. The LS black shales are expression of anoxic to dysoxic conditions at the bottom of the basin controlled by primary surface productivity and thermohaline oceanic circulation. Distribution of $\mathrm{Ba}$ and P2O5 throughout the LS emphasizes the role of enhanced productivity for the organic carbon accumulation. However, fluctuations in the curves of these elements compared with variations in the redox-sensitive element patterns suggest that periodically organic preservation was improved by low dissolved oxygen levels probably due to reduced oceanic circulation. Relatively high values of $\mathrm{P} 2 \mathrm{O} 5$, Ti and $\mathrm{Zr}$, coupled to the lowest_13C values and high Ba contents, recorded at the base of the Livello Selli, suggest high continental runoff and increased nutrient fluxes from continent to basin at the onset of the "Livello Selli deposition.

\section{References}

Bralower, T.J., CoBabe, E., Clement, B., Sliter, W.V, Osburn, C.L., Longoria, J., 1999. The record of global change in mid-Cretaceous (Barremina-Albian) sections from the Sierra Madre, northeastern Mexico. Journal of Foraminiferal Research, v. 29, pp. 418-437.

Erba, E., Channell, J.E.T., Claps, M., Jones, C., Larson, R., Opdyke, B., Premoli Silva, I., Riva, A., Salvini, G., Torricelli, S., 1999. Integrated stratigraphy of the Cismon Apticore (Southern Alps, Italy): A "reference section" for the Barremian-Aptian Interval at low latitudes. Journal of Foraminiferal Research, 29, 371-391.

Jenkyns, H.C., 1995, Carbon-isotope stratigraphy and paleoceanographic significance of the Lower Cretaceous shallow-water carbonates of Resolution Guyot, Mid-Pacific Mountains. In Winterer, E.L., Sager, W.W., Firth, J.V., Sinton, J.M. (Eds.), Proceedings of the Ocean Drilling Program, Scientific Results, 143, 99-108.

Menegatti, A.P., Weissert, H., Brown, R.S., Tyson, R.V., Farrimond, P., Strasser, A., Caron, M., 1998. High-resolution_13C stratigraphy through the early Aptian "Livello Selli" of the Alpine Tethys, Paleoceanography, 13, 530-545.

Moullade, M., Kuhnt, W., Berger, J.A., Masse, J., Tronchetti, G., 1998. Correlation of biostratigraphiv and stable isotope events in the Aptian historical stratotype of La B $\square$ doule (southeast France). Comptes Rendues Academie des Sciences, Paris, Science de la Terre et des Plan $\square$ tes, 327, 693-698. 